\title{
PEDAGOGICAL PARTNERSHIP OF PRESCHOOL EDUCATION INSTITUTIONS WITH PARENTS AS A CONDITION TO ENSURE THE QUALITY OF EDUCATION OF A CHILD
}

\section{ПЕДАГОГІЧНЕ ПАРТНЕРСТВО ЗАКЛАДУ ДОШКІЛЬНОЇ ОСВІТИ 3 БАТЬКАМИ ЯК УМОВА ЗАБЕЗПЕЧЕННЯ ЯКОСТІ ОСВІТИ ДИТИНИ}

\author{
Natalia Golota ${ }^{1}$ \\ Maryna Mashovets ${ }^{2}$
}

DOI: https://doi.org/10.30525/978-9934-26-001-8-1-2

Abstract. Modern preschool education in Ukraine is experiencing systemic changes in the structure and content of the educational process. The shift of emphasis on the acquisition of knowledge, skills and abilities to the acquisition of the necessary life competencies by the child, ensuring her personal growth puts forward new requirements for ensuring the quality of education of preschool children. However, the quality of preschool education today cannot be imagined without partner interaction between all subjects of the educational process: the administration of the institution, educators, parents, children. An institution of preschool education is an open educational space in which the teaching staff interacts with the families of pupils (as well as with other social institutions) to ensure the needs, interests and full development of each child. the interaction of the institution of preschool education and the families of pupils is an important condition for ensuring the effectiveness of the educational process aimed at creating an atmosphere of psychological comfort, goodwill and mutual understanding for all participants, based on traditional and modern pedagogical research in

\footnotetext{
${ }^{1}$ Candidate of Sciences in Pedagogy, Associate Professor, Associate Professor of the Department Pedagogical and Psychology, Borys Grinchenko Kyiv University, Ukraine

${ }^{2}$ Candidate of Sciences in Pedagogy, Associate Professor, Associate Director for Academic Affairs, Borys Grinchenko Kyiv University, Ukraine

(C) Natalia Golota, Maryna Mashovets
} 
the field of social and family education, takes into account regional, national and world culture, human and national moral values.

The purpose of our article is to characterize the pedagogical partnership of all subjects of the educational process of a preschool education institution as a necessary condition for ensuring the quality of a child's education.

It can be stated that a pedagogical partnership between a family and an educational institution in form is the coordination and implementation of the interests of the family and the teaching staff to ensure all conditions for the development and comfort of the child while striving to reach consensus and compromises on the most important issues of upbringing and training a growing personality.

The pedagogical partnership of the institution of preschool education and the family is realized in such components as: informational; the entry of the family into the educational space; active pedagogical position of the family in interaction with specialists.

Research findings. The process of professional training of teachers of preschool education of a new generation, who, already during the period of study in higher education institutions, created their own pedagogical style based on humanistic values, personal maturity, worldview positions, highlevel education, the ability to implement all virtues in practical activity, requires updating and improvement. in cooperation with the parents of the pupils. We consider the pedagogical partnership of an educator as one of the most active subjects of his attitude in the educational process of a preschool education institution, in three dimensions - children, parents, and the teaching staff.

The involvement of parents and families in the educational process of a preschool institution confirms the responsibility of each parent of a child for his upbringing, development and training, as well as for preserving her life, strengthening her health, forming a sense of human dignity and a conscious attitude of the child to a healthy lifestyle.

\section{1. Ветуп}

Сучасне суспільство ставить нові вимоги до якості освіти зростаючих поколінь, починаючи 3 дошкільного віку. Дошкільна освіта зазнає системних змін у структурі та змісті освітнього процесу. Перенесення акцентів з набуття знань, умінь і навичок до набуття дитиною 
необхідних життєвих компетентностей, забезпечення їі особистісного зростання висуває нові вимоги до забезпечення якості освіти дітей дошкільного віку.

Актуальність нашого дослідження визначається протиріччями, які сьогодні існують у дошкільній освіті: вихователь має стати фасилітатором, співтворцем індивідуальної освітньої траєкторії дитини, залучаючи до цього процесу родину дитини. Разом з тим, аналіз практики закладів дошкільної освіти свідчить, що роль вихователя в освітньому процесі залишається провідною. Насамперед, це пояснюється віковими особливостями дітей. Крім того, значна частина вихователів відчуває труднощі з налагодженням педагогічного партнерства з іншими учасниками освітнього процесу, особливо з батьками вихованців, враховуючи його визначальні характеристики: конструктивність у взаємодії, досягнення спільної мети за умов забезпечення рівності у правах та обов'язках сторін, розподілене лідерство. Позитивне, приязне спілкування між значущими для дитини дорослими сприятиме забезпеченню iii комфортного перебування в закладі дошкільної освіти та цілісному підходу до кожної дитини в освітньому процесі. До того ж вихователям інколи буває важко й осягнути сенс партнерської, суб'єкт-суб'єктної взаємодії насамперед в контексті взаємодії з вихованцями: а чи не буде педагогічне партнерство за суттю сприйматися дітьми як загравання 3 ними? Але педагогіка партнерства визначає істинно демократичний спосіб співпраці педагога і дитини, який не відкидає різниці в їхньому життєвому досвіді, знаннях, але передбачає безумовну рівність у праві на повагу, довіру, доброзичливе ставлення і взаємну вимогливість.

\section{2.Теоретичні основи дослідження}

Поняття «якість освіти» у філософському та педагогічному контекстах розглядалося вітчизняними вченими В. Андрущенко, В. Кременем, О. Локшиною, В. Огнев’юком, О. Савченко, С. Сисоєвою та іншими.

Питання якості дошкільної освіти знайшли висвітлення у працях Л. Артемової, Г. Рего, Л. Зданевич, О. Кононко, О. Коваленко, Л. Козак, К. Крутій, Т. Степанової, Н. Фроленкової та інших. Зазначені науковці розглядають зміст поняття «якість освіти» як надання можливостей вибору для дитини «індивідуального освітнього маршруту» на основі різноманітності змісту, форм і методів роботи з дітьми; забезпечення 
соціального захисту дитини від некомпетентних педагогічних дій; гарантія досягнення кожною дитиною мінімально необхідного рівня підготовки для успішного навчання в початковій школі [4].

Вислів «Якість слід показувати» відомого професора А.Д. де Грута (A.D. de Grut) досить часто цитують у наукових публікаціях, але досить мало описують як результати досягнення. Для закладу дошкільної освіти дуже важливо демонструвати свою справжню якість освіти, а для широкої громадськості визначити рівень якості розвитку закладу. Забезпечення якості дошкільної освіти - циклічний процес, який можна представити у такій формулі: бачення - вимірювання - контроль - удосконалення. Якість визначається за допомогою певних характеристик. Зупинимося на характеристиках, визначених у дослідженнях David A. Kolb (Д. Колба) [2] Навчальний цикл, виокремлений Д. Колба, та якість освіти взаємодоповнюються та взаємозбагачуються в процесі взаємодії учасників в ході освітньої діяльності. Д. Колба підкреслює, що навчальний цикл відбувається за таких мисленнєвих процесів: діяти - рефлексувати - думати-вирішувати (і знову) - діяти - рефлексувати, де діяти означає отримувати досвід; рефлексувати - обмірковувати отриманий досвід; думати - розуміти, аналізувати; вирішувати брати відповідальність.

Таблиця 1

Циклічна формула забезпечення якості освіти

\begin{tabular}{|c|l|l|}
\hline $\begin{array}{c}\text { № } \\
\text { 3/п }\end{array}$ & \multicolumn{1}{|c|}{$\begin{array}{c}\text { Циклічна формула } \\
\text { якості }\end{array}$} & \multicolumn{1}{c|}{ Навчальний цикл (за Д. Колбом) } \\
\hline 1.4. & бачення & дія (діяти) \\
\hline 2.3. & вимірювання & рефлексія (рефлексувати) \\
\hline 3.2. & контроль & аналіз та концептуалізація (думати) \\
\hline 4.1. & удосконалення & вибір рішення (брати відповідальність) \\
\hline
\end{tabular}

Саме процес «вирішувати» задля «удосконалення» у трактуванні «брати відповідальність» на себе має бути притаманним кожному суб'єкту освітнього процесу. Як зазначає К. Крутій, поняття «якість дошкільної освіти» характеризується суб'єктами освітнього процесу 3 урахуванням тих особливостей, які притаманні баченню кожного суб'єкта. Так, зазначає дослідниця, для держави - це соціальна та еко- 
номічна доцільність фінансових вкладень в освітні потреби суспільства. Власне для дітей дошкільного віку - це навчання в цікавій для них ігровій формі. Для батьків - це ефективне навчання, тобто навчання за програмами, що готують дітей до школи; конкретні результати освітньої роботи з їхньою дитиною. Для педагогів - це позитивна оцінка їхньої діяльності керівниками закладу, батьками; успішне виконання освітньої програми всіма дітьми; підтримка інтересу дітей до будь-якої діяльності, їхній успішний розвиток; збереження та зміцнення здоров'я кожної дитини; забезпечення педагогічного процесу всіма необхідними методичними рекомендаціями і системою планування. Для керівників - висока оцінка діяльності педагогів батьками і дітьми, підвищення престижу та іміджу дошкільного навчального закладу; раціональне використання часу дітей і педагога; успішність діяльності педагогів і дітей; повне засвоєння обраної освітньої програми та якісна підготовка дітей до школи $[8 ; 11 ; 12]$.

В контексті нашого дослідження особливий інтерес представляє думка К. Крутій про те, що для підвищення якості дошкільної освіти слід, насамперед, орієнтуватися на потреби конкретних споживачів освітніх послуг - дітей та їх батьків, враховуючи запити педагогів та соціальних партнерів, своєчасно виявляти й оцінювати реальний якісний стан освітньої системи, ії відповідність державним вимогам [9].

Л. Козак, визначаючи чинники та шляхи забезпечення якості сучасної дошкільної освіти, виділяє серед них і такий: забезпечення в закладі дошкільної освіти тісної взаємодії родини й медико-психолого-педагогічної служби; проведення медико-психолого-педагогічної експертизи для всіх новітніх технологій, рекомендованих до впровадження в освітній процес. Саме координація зусиль дасть змогу педагогам, психологам, медперсоналу й батькам забезпечити цілісність підходу до кожної дитини, інтеграцію змістових завдань і форм роботи. Педагоги мають пам'ятати, що саме батьки є замовниками послуг дошкільної освіти, та компетентно і доброзичливо допомагати їм, переконувати у можливостях дітей того чи іншого вікового періоду [6].

Питання взаємодія сім'ї та закладу освіти - складна проблема, що пройшла в своєму розвитку тривалий час, набуваючи різного змісту, характеризуючись різними підходами до ії̈ вирішення на різних етапах розвитку суспільства. 
На сьогодні сім’я відіграє визначальну роль не лише у формуванні особистості власної дитини, а й суспільства загалом. У публікаціях М. Машовець відзначається, що сучасна сім'я характеризується низкою особливостей у реалізації однієї з основних функцій - вихованні власних дітей, зокрема в період дошкільного дитинства. Серед цих особливостей виокремлюються найбільш актуальні, такі, як відповідальність за отримання дітьми якісної дошкільної освіти та можливості в реалізації батьківських прав бути партнером педагогічного колективу в освітньому процесі закладу дошкільної освіти. Неабияку роль у встановленні педагогічного партнерства з боку батьків відіграє якість сімейного виховання, що залежить від низки об'єктивних та суб'єктивних чинників, серед яких виділяють такі: тип сім'ї (повна, неповна, нуклеарна, багатопоколінна тощо), рівень загальної культури батьків, наявність сімейних традицій, розуміння необхідності наявності виховної моделі та засобів іiі реалізації, кількість дітей в сім’ї, відкритість батьків до збагачення власного педагогічного досвіду та розвитку виховних можливостей, здатність змінюватися й «зростати» разом $з$ дитиною. Держава забезпечує педагогічну підтримку та здійснює комплексний супровід сім'ї, в якій виховується дитина дошкільного віку, через систему суспільної дошкільної освіти.

Заклад дошкільної освіти - відкритий освітній простір, в якому педагогічний колектив взаємодіє із сім'ями вихованців (а також 3 іншими соціальними інституціями) задля забезпечення потреб, інтересів та повноцінного розвитку кожної дитини. Відвідування дитиною закладу дошкільної освіти не знімає із сім'ї обов'язку розвивати, виховувати та навчати дитину в родинному просторі. Сім'я не самоусувається від питань виховання власної дитини, а виступає замовником власного педагогічного просвітництва, що полягає в роз'ясненні батькам психологічних особливостей та можливостей дітей дошкільного віку на кожному віковому етапі дошкільного дитинства, провідних видів дитячої діяльності, значенні соціалізації для успішного розвитку дитини. Педагогічне просвітництво допомагає батькам усвідомити себе як відповідальних батьків, що розуміють власні ролі й функції у вихованні дітей та партнерами професіоналів, які забезпечують якісну дошкільну освіту дитини задля ії успішного розвитку; формують відповідні соціальні запити до системи дошкільної освіти з дотриманням 
потреб та інтересів дитини, а не задоволення своїх батьківських амбіцій чи вимог школи.

Упереджуючи загалом низький рівень престижу професії вихователя у сучасному суспільстві, наголошуємо на винятково важливій ролі закладу дошкільної освіти в педагогічному просвітництві сучасних батьків з питань розвитку, виховання та навчання дітей дошкільного віку через партнерську взаємодію.

Сім'я разом із закладом освіти забезпечує створення комплексу факторів і умов розвивального середовища та педагогічних впливів, що визначає ефективність всього освітнього процесу.

Однак, іноді в сімейному вихованні та у закладах дошкільної освіти простежується відсутність узгодженості щодо виховання та розвитку особистості дитини. Це ускладнює процес формування світогляду та правил поведінки дітей та не сприяє якості дошкільної освіти загалом. Лише конструктивна взаємодія з сім'єю допоможе забезпечити єдність вимог і виховних впливів на особистість дитини дошкільного віку.

Зауважимо, що взаємодія закладу дошкільної освіти та сімей вихованців $є$ важливою умовою забезпечення ефективності освітнього процесу, спрямованого на створення для всіх його учасників атмосфери психологічного комфорту, доброзичливості та взаєморозуміння, що спирається на традиційні та сучасні педагогічні дослідження в галузі суспільного та сімейного виховання, враховує регіональну, національну й світову культуру, загальнолюдські й національні моральні цінності.

Вивчення зарубіжного досвіду дало нам можливості відзначити, що в управлінні закладами дошкільної освіти у різних країнах світу вирізняють такі типи: адміністративне та партисипативне, тобто колегіальне, демократичне управління. Так, відомо, що вальдорфські школи (заклади дошкільної освіти в тому числі - «школи для маленьких») у Німеччині не мають керівника: управління закладом здійснюють педагогічний колектив разом з батьківським комітетом. Багато дошкільних закладів у різних країнах світу також не має адміністратора: функції управління здійснюють або педагогічний колектив або батьківський комітет на паритетних засадах. Однак, не дивлячись на привабливість саме демократичної форми управління, партисипативне далеко не завжди призводить до кращих результатів, порівняно з адміністративним. Позитивним $є$ те, коли у всіх учасників колегіаль- 
ного органу управління думки щодо розвитку та напрямів діяльності закладу співпадають, але досить часто не співпадають кардинально. Саме такий тип управління потребує консенсусу, рівноправності, здатності йти на компроміс і прийняти іншу точку зору.

\section{3. Методика та результати дослідження}

Загалом погоджуючись із основними позиціями, викладеними в роботах вітчизняних та зарубіжних науковців, (К. Крутій, Т. Піроженко, М. Рафальська та ін.), зазначимо ті особливості, які актуалізуються сучасними змінами в розумінні якості освіти через філософію концепції НУШ (2016).

Концептуальні засади Нової української школи спрямовують педагогів до залучення до впровадження в освітній процес двох основних новацій - компетентнісної парадигми освіти й педагогіки партнерства. Концепція Нової української школи проголошує якісно новий рівень побудови взаємодії між педагогами, учнями, їхніми батьками та громадськими організаціями - на основі гуманного та творчого підходу до кожного учасника освітнього процесу.

Педагогіка партнерства - напрям педагогіки, що включає систему методів і прийомів виховання та навчання на засадах гуманізму та творчого підходу до розвитку особистості. Грунтується на ідеях педагогіки: В. Сухомлинський, Ш. Амонашвілі (особливості гуманної педагогіки), О. Коханової (дослідження з психології партнерської взаємодії в освіті); С. Максименка (психологічні проблеми модернізації освіти в Україні); В. Моргуна (педагогічні засади співпраці, психологія толерантності); Г. Татаринцевої (методологічні підходи до визначення поняття «партнерство») та ін.

Одне із завдань педагогіки партнерства Ш. Амонашвілі сформулював таким чином: «Зробити дитину нашим (дорослих - учителів, вихователів, батьків) добровільним соратником, співробітником, однодумцем у своєму ж вихованні, освіті, навчанні, становленні, зробити їі рівноправним учасником педагогічного процесу, дбайливим і відповідальним за цей процес, за його результати» [3].

Партнерство є типом конструктивної взаємодії, спрямованої на досягнення спільної мети при рівності у правах та обов'язках сторін, і має широкий спектр застосування у всіх сферах соціальної системи, 
в тому числі й освітньої. При цьому важливим $є$ механізм узгодження різних позицій, наявність домовленостей (правил взаємодії), дотримання етичних норм. Можна констатувати, що педагогічне партнерство сім'ї та закладу освіти за формою - це узгодження та реалізація інтересів сім’ї та педагогічного колективу щодо забезпечення всіх умов для розвитку і комфорту дитини за умови прагнення досягнути консенсусу, компромісів 3 найважливіших питань виховання й навчання зростаючої особистості.

Загалом поняття «партнерство» переважно визначають як:

- систему взаємовідносин, що відбуваються у процесі певної спільної діяльності;

- спосіб взаємодії та взаємин, що виникають та розвиваються на принципах рівності, добровільності, рівнозначущості та доповнюваності всіх ії учасників;

- організаційну форму спільної діяльності, що передбачає об'єднання осібна відповідних умовах розподілу праці та активної участі в iï реалізації;

- спосіб взаємин, за яких зберігаються права кожної із сторін, чітко узгоджені й злагоджені дії учасників спільної справи, що грунтуються назасадах взаємовигоди та рівноправності [10].

Педагогіка партнерства за суттю - це демократичне та гуманне ставлення до дитини, забезпечення ій права на вибір, на відчуття власної гідності, на повагу, права на сприйняття ії такою, якою вона є, а не такою, якою хочуть іiі бачити батьки та педагог. Стосунки партнерства складаються лише тоді, коли діти та дорослі (батьки, педагоги, представники громадськості) об'єднані спільними поглядами й прагненнями та поважають і враховують бажання, позицію один одного. Педагогіка партнерства сприймає вихованця як добровільного, зацікавленого, рівноправного учасника освітнього процесу, який разом 3 іншими учасниками вболіває за його результати.

Педагогіка партнерства - чітко визначена система взаємин всіх учасників освітнього процесу (учнів, батьків, вчителів), яка:

- організовується на принципах добровільності й спільних інтересів;

- грунтується на повазі й рівноправності всіх учасників, дотримуючись визначених норм (права та обов'язки) та враховуючи ціннісні орієнтири кожної із сторін; 
- передбачає активне включення всіх учасників у реалізацію спільних завдань та готовність брати на себе відповідальність за їх результати [10].

Педагогічне партнерство закладу дошкільної освіти та сім’ї реалізується в таких складових, як: інформаційна; входження сім’ї в освітній простір; активна педагогічна позиція сім'ї у взаємодії з фахівцями.

Інформаційна складова передбачає усвідомлення дорослими батьками і фахівцями - дитини, іiї життя та здоров'я як найвищої цінності. Тому дорослі мають бути партнерами у забезпеченні належних умов для іï повноцінного розвитку. Для благополуччя дитини батьки повинні познайомитися 3 педагогічним колективом, особливостями роботи та відкритістю закладу дошкільної освіти, а фахівці у свою чергу мають на умовах конфіденційності володіти достовірною інформацією про стан її розвитку. Відкритість дорослих та координація їхніх дій сприятиме забезпеченню виконання материнської функції - охороні та зміцненню здоров’я дитини. Реалізація завдань даного аспекту допоможе утвердити батьків у позиції «відповідального батьківства», навчить їх розуміти та любити свою дитину, усвідомити унікальність періоду дошкільного дитинства, пріоритетність особистісного розвитку дитини, розвиток її творчого начала, а також усвідомити власну батьківську роль у житті дитини.

Входження сім’ї в освітній простір передбачає визначення прийнятного стилю взаємин 3 дитиною $з$ боку дорослих та між дорослими. Приймаючи дитину, вихователь має бути ознайомлений із змістом, характером і напрямком іiі виховання в сім'ї, щоб забезпечити умови підтримки того позитивного, що вже набуто. Конструктивна комунікація дорослих дасть можливість забезпечити діагностичну та конструкторсько-організаційну функції взаємодії батьків і вихователів.

Активна педагогічна позиція сім'ї у взаємодії з педагогічним колективом дошкільного навчального закладу, вихователем та помічником вихователя вікової групи, яку відвідує дитина, не тільки сприятиме поліпшенню реалізації функції педагогічного самовдосконалення батьків, а й допоможе дитині відчути себе захищеною й благополучною. Виділені складові педагогічної взаємодії можуть бути по-різному представлені в часі, здійснюватися послідовно або одночасно, але орієнтація вихователя на їх наявність допоможе керувати цим процесом. 
Взаємодія педагогічного колективу і сім'ї вихованців передбачає вирішення певних завдань:

- формування у батьків уявлень про необхідність взаємодії з педагогічним колективом;

- моделювання взаємодії педагогів і батьків на засадах індивідуального підходу до кожної сім'ї;

- розширення уявлень батьків про власну дитину, їі потенційні можливості й перспективи;

- популяризація ефективних педагогічних концепцій сімейного виховання дітей дошкільного віку;

- об’'еднання батьків за інтересами, створення сімейних клубів.

Модель включення батьків в освітній процес закладу дошкільної освіти грунтується на таких принципах:

- індивідуального підходу до кожної сім'ї;

- поєднання педагогічної самоосвіти та педагогічного просвітництва (батьків і вихователів);

- використання традиційних та нових форм взаємодії;

- урахування позитивного досвіду сімейного виховання.

Принцип індивідуального підходу передбачає проведення моніторингу соціального стану сім'ї, рівня педагогічної культури батьків та

стилю сімейного виховання; дослідження потреб, інтересів сімей; вивчення, узагальнення та популяризацію позитивного досвіду сімейного виховання; вивчення думок та бачення батьками результатів роботи дошкільного навчального закладу і якості взаємодії з педагогічним колективом.

Принцип поєднання педагогічної самоосвіти та педагогічного просвітництва (батьків і вихователів). Педагогічна самоосвіта - необхідна умова підвищення педагогічної культури як педагогів, так і батьків. Педагоги в процесі самоосвіти вивищують професійну компетентність, удосконалюють рівень теоретичних знань, ознайомлюються 3 інноватикою в освіті. Батьки відкривають для себе знання про закономірності розвитку і становлення особистості дитини, порівнюють свій виховний досвід з науково обгрунтованими методичними рекомендаціями взаємодії $з$ дітьми. Педагогічне просвітництво батьків 3 боку педагогів допомагає останнім зрозуміти особливості персоніфікованого виховного впливу на власну дитину, усвідомити необхідність 
побудови моделі сімейного виховання, суголосної з метою виховання щасливої дитини.

Принцип використання традиційних та нових форм взаємодії сім'ї та закладу дошкільної освіти полягає у доцільному поєднанні колективних форм підвищення педагогічної культури сім'ї з груповими та індивідуальними, з широким залученням інформаційно-комунікаційних технологій. Широкого поширення набувають он-лайн форм мережевої взаємодії дошкільного навчального закладу і сім’ї. Необхідним атрибутом іміджевої характеристики стає сайт закладу дошкільної освіти, створений та підтримуваний відповідно до чинних вимог. Визнання закладу дошкільної освіти відкритим освітнім та соціокультурним простором дає змогу запроваджувати такі нові форми взаємодії, як арт-студії, фан-клуби, літературні кафе з електронною бібліотекою для батьків.

Принцип урахування позитивного досвіду сімейного виховання полягає у використанні вихователем надбань сімейного виховання у розвитку дитини, традицій виховання, національних та релігійних особливостей i, відштовхуючись від них, проектуванні подальшого зростання педагогічної майстерності батьків.

Упровадження такої моделі взаємодії сім’ї і дитячого садка допомагає створювати в закладі дошкільної освіти поліфункціональне освітнє середовище, що характеризуватиметься мобільністю, змінюваністю, відкритістю, доступністю 3 метою надання дітям свободи вибору діяльності, а також включенням батьків у планування освітнього процесу та організацію процесу життєдіяльності дітей у групі, створенням творчої команди педагогів і батьків, що ефективно працюватиме над реалізацією завдань розвитку дітей дошкільного віку.

Залученість та участь педагогічного колективу в партнерському удосконаленні якості дошкільної освіти є ключовим фактором.

У межах конкретного закладу дошкільної освіти якість освіти визначається забезпеченням наступних умов: створенням належного розвивального середовища, кваліфікованим педагогічним персоналом, організацією освітнього процесу, інтенсифікацією впровадження в нього сучасних технологій і методів виховання й навчання, які дають можливості для розкриття творчої особистості, розвитку ініціативи, активізації пізнавальної діяльності дитини дошкільного віку. 
Сучасний освітній процес закладу дошкільної освіти неможливо уявити без ефективної комунікації між всіма його учасниками: адміністрацією, вихователями, батьками, дітьми, що потребує створення сприятливої атмосфери співробітництва, взаємодії на паритетних, партнерських засадах.

Комунікація та взаєморозуміння, особливо в освітній галузі, виконує досить вагому роль у встановленні партнерських взаємин між учасниками освітнього процесу. Загальновідомо, що в процесі комунікації беруть участь кілька співрозмовників (щонайменше двоє): відправник і отримувач/чі. Яку інформацію та як саме здобув отримувач, а також те, як він отриману інформацію інтерпретував, впливає на надання зворотнього зв'язку певним способом: або вербальним «Я не зовсім чітко зрозумів...», або невербальним - усмішка, жести похитування головою. Таким чином, суб'єкти комунікації змінюють свої ролі: отримувач стає відправником, а відправник - отримувачем. Підкреслимо, що не завжди процес комунікації відбувається продуктивно та легко. Саме тому, на практичних заняттях з фахових дисциплін, зокрема 3 дисципліни «Педагогічне партнерство» ми формуємо у студентів вміння доносити до отримувача істинне значення свого повідомлення. Дослідження свідчать, що безпосередньо процес комунікації означає більше, ніж фактичні слова. Так, 60\% інтерпретування повідомлення залежать від невербальної поведінки відправника - це і вібрації голосу, і вираз обличчя, і мова жестів, тощо. У наукових публікаціях (Тон Шоутен, Л. Даниленко, О. Зайченко, Н. Софій) виокремлено 4 аспекти комунікаційного повідомлення. Головне, щоб відправник та отримувач були впевнені в наявності всіх чотирьох аспектах: аспектний зміст - зміст інформації; аспект стосунків - ставлення того, хто посилає повідомлення до отримувача цього повідомлення; експресивний аспект - почуття, цінності, що характеризують самого відправника повідомлення, аспект звертання - активізація відправника повідомлення здійснювати або не здійснювати відповідні дії, що транслювалися в повідомленні.

Зазначені теоретичні положення, узагальнююча їх інтерпретація, адаптація до змісту професійної підготовки майбутніх дошкільних педагогів та включення в освітній процес при вивченні фахових дисциплін, дозволило нам перевірити ефективність та дієвість таких підходів. 
Нами було проведено дослідження стосовно того, наскільки майбутні вихователі готові до здійснення педагогічного партнерства у закладах дошкільної освіти з різними суб'єктами освітнього процесу: адміністрацією закладу, вихователями, батьками, та з самими дітьми. В центрі нашої уваги перебувала концепція комунікативної дії, зокрема питання взаєморозуміння (за Ю. Хабермасом). Вчений підкреслює, що поняття «взаєморозуміння» багатозначне. Воно означає, що суб'єкти однаково розуміють конкретне мовленнєве висловлювання і між ними існує згода щодо правильності висловлювання [1]. Загалом метою процесу взаєморозуміння є досягнення згоди, але зазвичай є розуміння або нерозуміння, нещирості або вимушеної згоди. В реальному житті згода може досягатися під впливом зовнішніх факторів, однак при цьому самими учасниками комунікації не буде вважатися власне згодою, так як грунтується на загальних переконаннях. Саме цей аспект комунікації цікавив нас при розгляді матеріалів педагогічної практики студентів. Адже ми припускали, що з точки зору комунікативного аспекту згоди важливий момент вимушеного визнання. Як зазначається в дослідженнях Ю. Хабермаса, саме суб'єктивне визнання змісту комунікаційних актів підкреслює раціональний характер практики взаєморозуміння [1].

Комунікативно досягнута згода має раціональну основу - стверджує науковець, пов'язуючи це із наявністю знань. Ю. Хабермас виділяє дві форми щоденної комунікації: «наївна» комунікативна дія і дискурс. Дискурс - це форма доведення комунікативної позиції за допомогою аргументації спірних позицій на значущість задля досягнення загальної згоди. Дискурс зазвичай організований за певними правилами: відкритість та рівність учасників; заборона примусу заради досягнення згоди; дії на засадах мотивації та аргументації. Тому важливим аспектом дослідження ми визначили налагодження суб'єкт-суб'єктної взаємодії на основі моделі комунікативної раціональності.

Дослідження ми проводили в процесі педагогічної практики студентів третього та четвертого курсів спеціальності «Дошкільна освіта» денної та заочної форм навчання.

Так під час спостереження за практикою студентів третього курсу денної форми навчання в закладах дошкільної освіти та проведеного опитування на початку та після завершення практики ми встано- 
вили, що майбутні вихователі у переважній більшості якнайлегшим (на початку педагогічної практики) вважали встановлення педагогічного партнерства 3 дітьми (84\% респондентів), 10\% вважали найбільш легким способом налагодження партнерських взаємин саме 3 вихователями та адміністрацією закладу), та лише 6\% респондентів припускали, що самим та ефективним та нескладним шляхом є налагодження партнерської взаємодії з батьками вихованців.

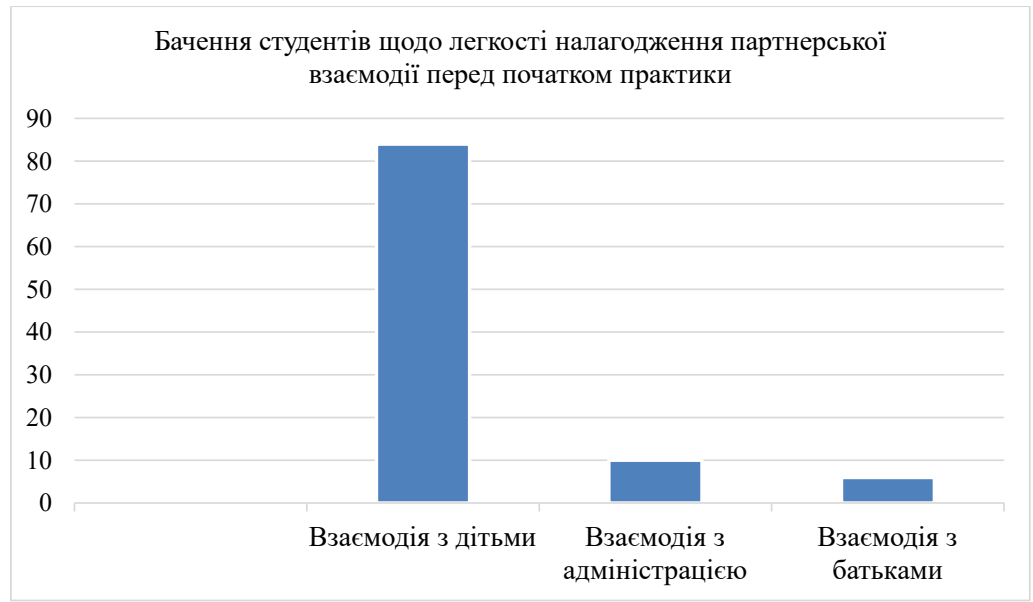

Однак, у ході педагогічної практики та після їі завершення, ті ж самі студенти змінили думку щодо легкості та ефективності налагодження партнерських взаємин з різними суб'єктами освітнього процесу.

Таблиця 2

Аналіз налагодження партнерської взаємодії по завершенню практики

\begin{tabular}{|l|c|c|c|}
\hline \multirow{2}{*}{$\begin{array}{l}\text { Очікування студентів } \\
\text { до початку практики }\end{array}$} & \multicolumn{3}{|c|}{ Реальний стан у практиці встановлення взаємодії } \\
\cline { 2 - 4 } & дітьми & $\begin{array}{c}\text { 3 адміністрацісю } \\
\text { та колегами }\end{array}$ & 3 батьками \\
\hline 3 дітьми $-84 \%$ & $81 \%(-3)$ & & \\
\hline 3 адміністрацією-10\% & & $11 \%(+1)$ & \\
\hline 3 батьками -6\% & & & $8 \%(+2)$ \\
\hline
\end{tabular}


Отримані матеріали дали цікаві дані для аналізу питання загалом. Так зокрема, ті студенти, які вважали, що найпростішим способом встановлення партнерських взаємин з суб'єктами освітнього процесу є саме взаємодія $з$ дітьми дошкільного віку, зазначили, що вихованці виявилися не зовсім такими, як вони очікували: значний відсоток дітей $(62 \%)$ охоче йде на контакт, приязно та із задоволенням приймаючи деякі правила педагогічного партнерства: вони охоче йдуть на контакт, ввічливо ставляться та позитивно сприймають педагога, однолітків; певний відсоток дітей (19\%) самостійної активності не виявляють, однак, за пропозицією вихователя, взаємодіють з ними, водночас $19 \%$ дітей не готові до рівноправного сприйняття інших - що дітей, що дорослих, а саме - наполягають на своїй точці зору, часто ображаються, якщо їм пропонують консенсус; у цьому випадку уникають контактів. Тож різниця між очікуваною та реальною взаємодією 3 дітьми склала $3 \%$. Аналізуючи очікування та реальні досягнення взаємодії з батьками, отримали такі результати: 8\% респондентів зазначили, що батьки більш охоче йдуть на контакт 3 вихователями, так і 3 ними - практикантами, ніж вони собі уявляли. Студенти із задоволенням зазначали, що батьки цікавляться їх думкою, як майбутніх педагогів, потребують їхньої допомоги. В даній позиції різниця складає $2 \%$ більше, ніж очікувалося. Припускаємо, що цей результат обумовлений підтримкою студентів та мотивацією їх до оволодіння педагогічною професією.

Щодо взаємодії батьків і вихователів на завершення практики 91\% студентів третього курсу загалом відзначили, що переважна більшість батьків вихованців (86\%) цікавляться думкою педагогів, 74\% 3 них потребують педагогічної підтримки у справі виховання власної дитини, так як переймаються тим, чи все вони роблять правильно в цьому контексті.

Щодо взаємодії з адміністрацією та колегами різниця між очікуваннями та реальними здобутками склала $1 \%$ збільшення. Ми пояснюємо такі показники рядом об'єктивних та суб'єктивних причин, які плануємо проаналізувати в наступних публікаціях.

Разом 3 тим, більшість студентів зазначили, що їм, як майбутнім вихователям, ще з ряду причин, серед яких зазначаються обмежені терміни практики, складно досягти ефективної педагогічної взаємодії як 3 дітьми, як з їх батьками, так із педагогами закладу - не вистачає власних 
умінь знаходити компроміс у спілкуванні, проєктувати та пропонувати вдалі вирішення питань розвитку навчання та виховання дошкільнят.

Слід зазначити, що студенти третього курсу заочної форми навчання, що переважно є практиками дошкільної освіти, більш легко знаходили контакт з дітьми та колегами; водночас вони зізнавалися у нестачі знань та вмінь вибудовувати взаємини з батьками, залучаючи останніх до проєктування освітньої траєкторії їх дитини.

Стосовно практики студентів четвертого курсу денної форми навчання, зауважимо, що переважна їх більшість - 87\% не лише ефективно встановлювала взаємини з дітьми, але й опосередковано сприяла налагодженню взаємин дітьми у групі, вміло вибудовувала взаємини 3 наставниками - вихователями групи. Однак певна кількість студентів $-44 \%$ висловлювали занепокоєння стосовно налагодження взаємин з батьками вихованців - батьки й матері дітей або не прислухалися до молодих педагогів переважно через їх юний вік, або через власне переконання у правильності виховання власної дитини в умовах сім'ї.

Натомість 92\% студентів четвертого курсу заочної форми навчання зазначали, що їм вдається ефективно та вчасно налагодити взаємини між усіма учасниками освітнього процесу, водночас 65\% з них зізналися, що досить важко спрямувати батьків на зміну установок у вихованні, які вони транслюють власним дітям.

Слід зазначити, що в умовах реального педагогічного партнерства, всі суб'єкти освітнього процесу змінюються: дитина формується як особистість за результатами єдності та синхронізації виховних впливів; батьки починають глибше розуміти не лише особливості організації освітнього процесу в закладі дошкільної освіти, але й особливості розвитку власної дитини, насамперед, вікові, що призводить до більш відповідального виховання дитини в умовах сімейного виховання, а інколи - змінюють погляди на виховання та потреби власної дитини, змінюють виховні або соціальні установки, що транслюють їй (свідомо чи несвідомо). Вихователі мають можливість більше дізнатися про своїх вихованців, застосовувати знання та інтереси батьків в освітньому процесі, залучати їх до життєдіяльності групи, закладу.

Говорячи про організацію педагогічного партнерства в закладі дошкільної освіти, не можемо оминути створення ефективного інформаційного простору не лише як засобу входження дитини дошкільного 
віку в інформаційно-технологічно інформаційне суспільство, але й як управлінського ресурсу та засобу ефективної комунікації між всіма суб'єктами освітнього процесу. Інформаційно-освітнє середовище сприяє створенню умов для особистісно-орієнтованої взаємодії всіх суб'єктів освітнього процесу.

В контексті вищезазначеного, взаємодію між адміністрацією, вихователями та батьками вихованців закладу дошкільної освіти можна схарактеризувати як процес, що грунтується на партнерських взаєминах, конструктивній взаємодії, організації спільної діяльності, інформаційного зв' язку, взаємовпливі, взаєморозумінні. Програма такої взаємодії має бути чіткою та комплексною, та (приблизно) може включати такі напрями:

- діагностика виховних можливостей сімей вихованців, їх освітніх та соціокультурних потреб і запитів, очікування стосовно виховання та навчання їх дитини;

- вивищення рівня педагогічної культури батьків;

- проєктування різних форм взаємодії ЗДО із сім'єю, наповнення їх сучасним змістом, а саме новітніми підходами до організації виховного процесу в умовах сімейного виховання, в тому числі й дозвілля із залученням можливостей закладу освіти;

- створення єдиного інформаційного простору, що сприяє встановленню паритетних взаємин між адміністрацією, педагогічним колективом, вихованцями та їх батьками.

В цьому контексті хочемо зазначити, що взаємодія педагогів, дітей та їх батьків потребує об'єднання зусиль адміністрації, вихователів, сімей вихованців та представників інших соціальних інституцій.

\section{4. Висновки}

Проведене нами дослідження не вичерпує розгляд проблеми реалізації педагогічного партнерства в освітньому процесі закладу дошкільної освіти. Потребує оновлення та удосконалення процес професійної підготовки педагогів дошкільної освіти нової генерації, які б вже в період навчання в закладах вищої освіти створювали власний педагогічний стиль, заснований на гуманістичних цінностях, особистісній зрілості, світоглядних позиціях, освіченості високого рівня, здатностях до реалізації всіх чеснот в практичній діяльності у взає- 
модії з батьками вихованців. Ми розглядаємо педагогічне партнерство дошкільного педагога, як одного із найактивніших суб' єктів його встановлення в освітньому процесі ЗДО, у трьох площинах - діти, батьки, педагогічний колектив.

Залучення батьків і сімей до освітнього процесу закладу дошкільної освіти утверджує відповідальність кожного із батьків дитини за їі виховання, розвиток і навчання, а також за збереження ії життя, зміцнення здоров'я, формування почуття людської гідності та усвідомленого ставлення дитини до здорового способу життя.

\section{Список літератури:}

1. Habermas J. (2004) Die Theorie des kommunikativen Handelns - eine AnalyseHausarbeit (Hauptseminar). Martin-Luther-Universität Halle-Wittenberg (Institut für Soziologie).

2. Kolb D. (1993). Learning Style Inventory. Boston, MA: McBer and Company. Retrieved from: http://med.fau.edu/students/md_m1_orientation/M1\%20Kolb\%20 Learning\%20Style\%20Inventory.pdf

3. Амонашвили Ш.А. Размышления о гуманной педагогике. Москва : Издательский Дом Шалвы Амонашвили, 1996. 496 с.

4. Дошкільна освіта : словник-довідник. Словник-довідник, 2010. 293 с.

5. Енциклопедія освіти. Акад. пед. наук України; головний ред. В.Г. Кремень. Київ : Юрінком Інтер, 2008. 1040 с.

6. Козак Л., Швидка I. Якість дошкільної освіти на сучасному етапі. Освітологічний дискурс. 2018. № 3-4. C. 22-23. URL: http://elibrary.kubg.edu.ua/ id/eprint/25257/1/\%2BKozak_yakist_osvita.pdf

7. Концепція «Нова українська школа». 2016. URL: https://osvita.ua/doc/ files/news/520/52062/new-school.pdf

8. Крутій К.Л. Моніторинг як сучасний засіб управління якістю освіти в дошкільному навчальному закладі : монографія. Запоріжжя : ТОВ "ЛІПС" ЛТД, 2006. $172 \mathrm{c.}$

9. Крутій К. Методологічні аспекти моніторингу дошкільної освіти. Вісник СевНТУ. вип. 105: Педагогіка: зб. наук. пр. Севастополь : Вид-во СевНТУ, 2010. С. 23-26. URL: http://sevntu.com.ua/jspui/bitstream/ 123456789/2277/1/105-05.pdf

10. «Педагогіка партнерства» як один із факторів ефективної взаємодії учасників освітнього процесу. 2018. URL: https://vseosvita.ua/library/dopovidpedagogika-partnerstva-ak-odin-iz-faktoriv-efektivnoi-vzaemodii-ucasnikivosvitnogo-procesu-76309.html

11. Фроленкова Н.О. Якість дошкільної освіти в Україні: феномен поняття. Молодий вчений. 2015. № 2(17). С. 116-118.

12. Янко О.В. Організаційно-педагогічні умови управління якістю роботи сучасного дошкільного навчального закладу (PhD Thesis). Луганськ, 2009. 


\section{References:}

1. Habermas J. (2004). Die Theorie des kommunikativen Handelns - eine AnalyseHausarbeit (Hauptseminar). Martin-Luther-Universität Halle-Wittenberg (Institut für Soziologie).

2. Kolb D. (1993). Learning Style Inventory. Boston, MA: McBer and Company. Retrieved from: http://med.fau.edu/students/md m1_orientation/M1\%20Kolb\%20 Learning\%20Style\%20Inventory.pdf (accessed $\overline{2} 1.1 \overline{0} .2020$ ) .

3. Amonashvili Sh.A. (1996). Razmyshleniya o gumannoy pedagogike [Reflections on humane pedagogy]. Moskva: Izdatel'skiy Dom Shalvy Amonashvili, 496 p. (in Russian)

4. Doshkiljna osvita: slovnyk-dovidnyk (2010) [Preschool education: dictionary-reference book], 293 p. (in Ukrainian)

5. Encyklopedija osvity (2008) [Encyclopedia of Education] Akad. ped. nauk Ukrajiny; gholovnyj red. V.Gh. Kremenj. Kyiv: Jurinkom Inter, 1040 p. (in Ukrainian)

6. Kozak L., Shvydka I. (2018). Jakistj doshkiljnoji osvity na suchasnomu etapi [The quality of preschool education at the present stage]. Osvitologhichnyj dyskurs, vol. 3-4, pp. 22-23. Retrieved from: http://elibrary.kubg.edu.ua/id/ eprint/25257/1/\%2BKozak_yakist_osvita.pdf (accessed 21.10.2020).

7. Koncepcija «Nova ukrajinsjka shkola» (2016) [The concept of the New Ukrainian School]. Retrieved from: https:/osvita.ua/doc/files/news/520/52062/ new-school.pdf (accessed 21.10.2020).

8. Krutij K.L. (2006). Monitoryngh jak suchasnyj zasib upravlinnja jakistju osvity $v$ doshkiljnomu navchaljnomu zakladi: monoghrafija [Monitoring as a modern means of managing the quality of education in preschool education: a monograph]. Zaporizhzhja: TOV "LIPS" LTD, 172 p. (in Ukrainian)

9. Krutij K. (2010). Metodologhichni aspekty monitorynghu doshkiljnoji osvity. [Methodological aspects of monitoring preschool education]. Visnyk SevNTU. Vol. 105: Pedaghoghika: zb. nauk. pr. Sevastopolj: Vyd-vo SevNTU, pp. 23-26. Retrieved from: http://sevntu.com.ua/jspui/bitstream/123456789/2277/1/105-05.pdf (accessed 21.10.2020).

10. «Pedaghoghika partnerstva» jak odyn iz faktoriv efektyvnoji vzajemodiji uchasnykiv osvitnjogho procesu (2018) [ «Pedagogy of partnership» as one of the factors of effective interaction of participants in the educational process] Retrieved from: https://vseosvita.ua/library/dopovid-pedagogika-partnerstva-ak-odin-iz-faktorivefektivnoi-vzaemodii-ucasnikiv-osvitnogo-procesu-76309.html (accessed 21.10.2020).

11. Frolenkova N.O. (2015). Jakistj doshkiljnoji osvity v Ukrajini: fenomen ponjattja [The quality of preschool education in Ukraine: a phenomenon]. Molodyj vchenyj, vol. 2(17), pp. 116-118. (in Ukrainian)

12.Janko O.V. (2009). Orghanizacijno-pedaghoghichni umovy upravlinnja jakistju roboty suchasnogho doshkiljnogho navchaljnogho zakladu [Organizational and pedagogical conditions of quality management of a modern preschool educational institution] ( $\mathrm{PhD}$ Thesis), Lughansjk. 